УДК 352 (091) (430)

doi:10.15421/151632

Еволюція системи місцевого самовряаування у Німеччині (на приклаАі землі БранАенбург): історико-управлінський аспект

\author{
О. Я. КРАСІВСЬКИЙ, М. М. ЯНИШЕВСЬКИЙ \\ Аьвівський регіональний інститут Аержавного управління Національної акалемії дер- \\ жавного управління при Презилентові України, Аьвів-Брюховичі, \\ Україна
}

\begin{abstract}
Авторське резюме
Детально проаналізовано розвиток системи місцевого самоврядування у Німеччині на прикладі громад землі Бранденбург. Охарактеризовано історичні моделі організації влади на базовому рівні місцевого самоврядування: магістратну, північнонімецьку, південнонімецьку та рейнську бургомістерську. Запропоновано етапи еволюції місцевого самоврядування громад землі Бранденбург: утвердження міст як автономних центрів політичного, економічного та культурного життя; розвиток врядування в умовах магдебурзького права; перетворення місцевого самоврядування у низову ланку суперцентралізованого державного управління Пруссії; розвиток магістратного типу управління та встановлення основ сучасної моделі місцевого самоврядування Бранденбурга; муніципальний устрій в умовах тоталітаризму; проведення сучасної муніципальної реформи.

3'ясовано новітні тенденції розвитку муніципального управління. Встановлено, що муніципальний устрій більшості федеральних земель грунтується на південнонімецькій моделі, яка виражається у двох варіантах: «рада - бургомістр з одним управлінським центром» та «рада - бургомістр з подвійним управлінським центром». Наголошено на необхідності дослідження ефективності та доцільності використання елементів німецької системи місцевого самоврядування в Україні.

Ключові слова: магістратний вид управління; південнонімецький вид управління; модель «рада - бургомістр з одним управлінським центром»; модель «рада - бургомістр 3 подвійним управлінським центром»; муніципальна реформа; громада
\end{abstract}

\title{
The evolution of local governments' system in Germany (based on the example of Brandenburg): historical and administrative aspects
}

\author{
O. YA. KRASIVSKYY, M. M. YANYSHEVSKYY \\ Lviv regional institute of public administration National academy of public \\ administration, the Office of the President of Ukraine, Lviv-Briukhovychi, Ukraine
}

\section{Abstract}

The development of local governments in Germany on the example of communities in Brandenburg was analyzed in details. The study characterizes historical models of governance at the basic level of local government - magistrate, Northern German, Southern German and Rhine burgomaster. The following stages of local government evolution in Brandenburg were proposed: establishment of cities as autonomous centers of political, economic and cultural life; development of governance under the conditions of Magdeburg Law; transformation of local government in grassroots super centralized governance of Prussia; development of magistrate management type and establishing foundations of a modern model of local self-governance in Brandenburg; municipal system in terms of totalitarianism; implementation of modern municipal reform.

The study shows the latest trends of municipal government were shown. It was found that the municipal structure of the majority of federal states was based on the Southern German model. It is implemented in two ways: »council - mayor with one management center» and »council - mayor with dual management center.» The necessity to study the efficacy and feasibility of using elements of the German system of local government in Ukraine was highlighted.

(c) О. Я. Красівський, М. М. Янишевський, 2016 
Key words: magistrate type of governance; South German type of governance; model »council - mayor with one management centre»; model »council - mayor with dual management centre»; municipal reform; community

\title{
Эволюция системы местного самоуправления в Германии (по примеру земли БранАенбург): историко-управленческий аспект
}

\author{
О. Я. КРАСИВСКИЙ, М. М. ЯНЫШЕВСКИЙ \\ Аьвовский региональный институт госуАарственного управления Национальной \\ акалемии государственного управления при Презиленте Украины, \\ Аьвов-Брюховичи, Украина
}

\begin{abstract}
Авторское резюме
Подробно проанализировано развитие системы местного самоуправления в Германии на примере общин земли Бранденбург. Охарактеризовано исторические модели организации власти на базовом уровне местного самоуправления: магистратная, северогерманская, южногерманская и рейнская бургомистерская. Предложено этапы эволюции местного самоуправления общин земли Бранденбург: утверждение городов как автономных центров политической, экономической и культурной жизни; развитие управления в условиях магдебургского права; преобразования местного самоуправления в низовое звено суперцентрализованного государственного управления Пруссии; развитие магистратного типа управления и установление основ современной модели местного самоуправления Бранденбурга; муниципальный строй в условиях тоталитаризма; проведение современной муниципальной реформы.

Выяснено новейшие тенденции развития муниципального управления. Установлено, что муниципальный строй большинства федеральных земель Германии основывается на южногерманской модели, которая выражается в двух вариантах: «совет - бургомистр с одним управленческим центром» и «совет - бургомистр с двойным управленческим центром». Отмечена необходимость исследования эффективности и целесообразности использования элементов немецкой системы местного самоуправления в Украине.
\end{abstract}

Ключевые слова: магистратный вид управления; южногерманский вид управления; «совет - бургомистр с одним управленческим центром»; «совет - бургомистр с двойным управленческим центром»; муниципальная реформа; община

Постановка проблеми. Українська держава розпочала здійснювати перші кроки у впровадженні муніципальної реформи. Аналіз та оцінка доцільності впровадження зарубіжного досвіду розвитку інституту місцевого самоврядування є необхідним компонентом у процесі реалізації глибоких та системних змін в Україні. Особливу увагу необхідно звернути на досвід держав, які стояли в історичних витоків сучасної європейської системи місцевого самоврядування, пережили час фактичної відсутності демократичного врядування в умовах тоталітаризму та змогли успішно подолати його негативні наслідки шляхом переходу від радянсько-соціалістичної моделі до сучасних ефективних систем управління самоврядними одиницями. До та-

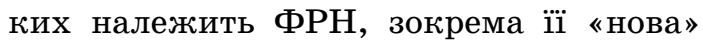
федеральна земля Бранденбург. Детальне дослідження історичних та сучасних моделей організації місцевої самоврядної влади в Німеччині, а також еволюції муніципального управління в громадах Бранденбурга посилить інтерес ідеологів децентралізації влади в Україні до використання успішного досвіду ФРН у створенні спроможної системи місцевого самоврядування.

Аналіз досліджень та публікацій. Проблема становлення та розвитку місцевого самоврядування в Німеччині досліджена в окремих працях О. Батанова, О. Бориславської, А. Георгіци, I. Дробота, М.Кобилецького, В. Куйбіди, П. Любченка, Ю. Панейка, С. Різника, А. Ткачука. Процеси формування та 
функціонування представницьких органів публічної самоврядної влади зарубіжних країн висвітлені у науковій розробці А. Лазора, О. Лазора, Х. Кохалик, І. Шелепницької і М. Коваль [2]. У дисертаційному дослідженні Х. Кохалик проведено характеристику особливостей організаційно-правового статусу територіальної громади, її посадових осіб, процеси здійснення міського самоврядування у громадах Німеччини [1]. Зважаючи на те, що становлення німецької системи місцевого самоврядування характеризується особливостями у різних федеральних землях, на сьогодні відсутні грунтовні дослідження цієї проблематики на прикладі конкретних земель, зокрема у Бранденбурзі.

Метою дослідження $є$ аналіз еволюції системи місцевого самоврядування у громадах землі Бранденбург у контексті історичних та сучасних моделей муніципального устрою Німеччини.

Виклад основного матеріалу. Витоки німецького місцевого самоврядування пов'язані з активним розвитком міст на межі XI-XII століть. В цей час формується система гільдій та цехів, до яких входять міщани за родом їх професійної діяльності. 3 часом ці промислово-політичні об'єднання розпочали боротьбу з феодалами, яким, як правило, належали міста, за право брати участь у вирішенні місцевих справ. Результатом стало запровадження з XIII ст. автономії міста у прийнятті правових актів. 3 того часу бере свій початок магдебурзьке право, яке швидко поширилося, зокрема у марці Бранденбург, Померанії, Саксонії, Тюрінгії, Сілезії та набуло особливого значення для розвитку міст у Центрально-Східній Європі.

В часи абсолютизму в Свропі незалежність міст та будь-яких інших громад була скасована. Місто стало звичайною адміністративно-територіальною одиницею в максимально централізованій абсолютистській системі державного управління. Рада міста перестала бути органом самостійної громади, а перетворилася на інструмент реалізації необмеженої волі суверена. Відповідно до положень Загального Зводу земельного права Пруссії 1794 р. міста мали право так званого «привілейованого органу». Насправді ж будь-які повноваження громада могла отримати лише як акт доброї волі держави. Німецька наукова думка стверджує, що від колишньої автономії місцевого самоврядування не залишилося жодного сліду [8, с. 29].

Лише на поч. XIX ст. ідея громадівського самоврядування знову ожила, отримавши нові правові основи в процесі впровадження в Пруссії реформ Штайна-Гарденберга. Кардинальні зміни торк нулися системи міського управління. В Положенні про міста Прусської монархії від 19.11.1808 р. запропоновано модель міста, управління яким здійснюють його жителі. Вони обирали депутатів на громадських засадах до представництва (ради) міста на основі нової куріальної виборчої системи. Цей орган здійснював представництво інтересів міщан у всіх місцевих справах. 3-поміж депутатів обирався голова ради. Іншим місцевим органом влади був магістрат. Цей колективний управлінський орган обирався радою міста й був підконтрольний їй. Голова магістрату також обирався радою міста та здійснював повноваження на постійній основі. Магістрат був наділений компетенцією у підготовці та виконанні рішень ради міста, а також вирішував справи поточного управління.

Завдяки реформаторським крокам Штайна сформувалася перша історична модель муніципального управління магістратна. На сьогодні у первинному вигляді ця модель поширена у громадах землі Гессен. Зазначимо, що в основу муніципального управління було закладено принцип розмежування функцій підготовки, прийняття та виконання рішень органів місцевого самоврядування. Ця тричленна модель розподілу управлінських функцій залишається основою системи повноважень органів влади громади та їх взаємовідносин у наш час.

Особливої уваги також заслуговує те, що Положення про міста Прусської монархії є джерелом сучасної федеральної гарантії місцевого самоврядування, закріпленої в ч. 2 ст. 28 Основного Закону ФРН [12]. Принцип «універсальної 
(всесторонньої) юрисдикції» громади, поділ повноважень на власні (самоврядні) й делеговані (державні), а також виключно правовий характер державного нагляду за діяльністю органів місцевого самоврядування започатковані саме у Положенні Штайна.

Після Віденського конгресу 18141815 pp. у багатьох європейських державах відбулася реставрація влади старих абсолютистських сил, яка супроводжувалася постійним конфліктом між державою та суспільством. Результатом цього протистояння стали революційні події 1848-1849 рр. в Свропі, які поширилися й на держави Німецького союзу. Франкфуртські національні збори, які були першим загальнонімецьким парламентом, прийняли першу німецьку конституцію (Конституція Паульскірхе) в березні 1849 р. Поряд з нормами про створення єдиної німецької держави та законодавчого закріплення основних прав людини, конституція у частині VI статті XI § 184 встановлюе право кожної громади на: а) обрання голови й представників; б) самостійне управління й вирішення місцевих справ, включаючи муніципальну поліцію, при наявності законодавчо визначеного загального державного нагляду; в) оприлюднення муніципального бюджету; г) відкритість засідань органів влади як обов'язок [17]. Незважаючи на те, що Конституція Паульскірхе так і не набрала законної сили, § 184 відкрив нову еру в розумінні місцевого самоврядування. На відміну від громади як органічного структурного елемента державної системи (Штайн), поширюється ідея вільної громади як суспільної інституції, яка протиставляється державі. Як бачимо, у Німеччині XIX ст. розвиваються паралельно державницька та громадівська теорії місцевого самоврядування.

Відповідно до змісту нового Положення про громади в Прусській державі 1850 р. відбувається уніфікація муніципального права на всій території монархії, зокрема у громадах Бранденбурга. Первинним суб'єктом виступає об'єднана громада, жителі якої обирають на основі трикласної виборчої сис- теми виконавчий орган та раду громади. Внутрішня організація влади та відносини між органами будувалися на основі традиційного магістратного типу управління.

Взявши за основу Конституцію Паульскірхе, Веймарська конституція 1919 р. у ст. 127 гарантує громадам та округам право самоврядування в межах закону [6]. В науці та практиці виникла дискусія щодо правового змісту згаданої статті. В кінці 20-х pp. ХХ ст. панівною стало розуміння, що у ст. 127 йде мова про конституційно-правову інституційну гарантію, яка захищає право громад на місцеве самоврядування від скасування і дискредитації $[16$, с. 1]. Сучасна наукова думка по-іншому оцінюе зміст ст. 127. Альфонс Герн вважає, що це була мертва норма-декларація, яка розділила сумну долю інших положень Веймарської конституції про основні права: вони були порожні за змістом і не зобов'язували законодавця їх дотримуватися [8, с. 49]. I лише з прийняттям Основного Закону 1949 р. остаточно утвердилося розуміння інституційного характеру гарантії місцевого самоврядування та механізм їі захисту.

3 приходом до влади націонал-соціалістів відбувається процес ліквідації незалежної від державної влади системи муніципального управління. Відповідно до Закону про муніципальний устрій 1933 р. встановлювалася єдина система органів місцевого самоврядування у громадах та округах колишньої Пруссії, які входили до Німецької Імперії. Бургомістр (голова громади) призначався міністром внутрішніх справ після консультацій 3 гауляйтером Націонал-соціалістичної робітничої партії Німеччини (НСДАП). Склад рад громад, до яких входили представники НСДАП, CA i CC за посадами, визначався органом державного нагляду за пропозицією гауляйтера [7, с. 672]. Німецьке Положення про громади 1935 р. вводить єдине уніфіковане муніципальне право на всій території держави [4]. Незважаючи на те, що ч. $2 \S 1$ Положення формально надає громадам право на управління місцевими справами під власну відпові- 
дальність, насправді метою цього закону була ліквідація демократичних парламентарних структур на місцевому рівні та встановлення повного підпорядкування громад владній волі тоталітарної унітарної держави.

Поразка Німеччини у Другій світовій війні, поділ їі території на американську, англійську, французьку, радянську зони окупації та, як наслідок, утворення двох окремих німецьких держав істотно вплинули на розвиток системи місцевого самоврядування. На території сучасної Нижньої Саксонії та Північного Рейн-Вестфалії під впливом англо-американського розуміння місцевого самоврядування формується північнонімецький тип муніципального управління. Моністична модель управління передбачала особливо сильний правовий статус представництва (ради) громади та відносно слабкого керівника муніципальної адміністрації, який є інструментом реалізації політики представницького органу. Голова ради (бургомістр) обирався 3-поміж депутатів на громадських засадах, здійснював політичне керівництво громадою та представляв її інтереси.

Систему виконавчих органів очолював обраний радою директор-менеджер громади, який здійснював передані радою повноваження на платній основі та міг бути усунений з посади кваліфікованою більшістю депутатського корпусу. Недоліком цього типу управління був часто незрозумілий розподіл компетенції між бургомістром та директором виконавчих органів. Це породжувало дуб лювання функцій між цими суб'єктами та не сприяло ефективності роботи органів місцевого самоврядування. Як наслідок, у ході масштабної муніципальної реформи середини 90-х років ХХ ст. північнонімецький вид муніципального устрою перестав існувати.

На території Баварії, Вюртемберга та Бадена остаточно формується південнонімецький тип муніципального управління. Дуалістичний характер цієі моделі зумовлений тим, що між двома обраними жителями представницькими органами - радою і бургомістром
- розділена компетенція щодо вирішення справ місцевого значення. Типовою ознакою цього типу організації місцевої самоврядної влади є сильне позиціонування бургомістра в системі владних відносин, яке передбачає концентрацію істотних повноважень в одній особі, перетворюючи бургомістра на політичного лідера громади.

Бургомістр очолюе раду, має право голосу на їі засіданнях та у депутатських комісіях, очолює всю вертикаль виконавчих органів муніципалітету та представляе інтереси громади у відносинах 3 іншими суб'єктами публічної влади, об'єднаннями громадян, юридичними особами й в судових процесах. Важливим чинником ключової ролі бургомістра у південнонімецькій моделі $\epsilon$ не лише реалізація частини компетенції ради, переданої бургомістру, але й здійснення власних (самоврядних) повноважень щодо вирішення справ поточного управління та виконання делегованих (державних) функцій. Подібним за ознаками є рейнський бургомістерський тип, який був притаманний громадам Райнланд-Пфальц, Саарланду та Шлезвіг-Гольштайну до 1998 р.

Територія сучасного Бранденбурга ввійшла до радянської зони окупації, в якій було видано Демократичне положення про громади 1946 р., яке поширювалося поряд 3 Бранденбургом на Померанію, Саксонію, Тюрінгію та Саксонію-Ангальт [3]. Відповідно до $\S 1$ цього документа самоврядна громада повинна була стати основою демократичного устрою. Визнавався принцип «універсальної юрисдикції» громади (§ 3), поділ повноважень на власні й делеговані $(\S \S 4,5)$. Вищим органом волевиявлення було представництво (рада) громади, яка обиралася ¥ї жителями на два роки. Компетенція ради поширювалася на локальне нормотворення, формування бюджету та всі інші справи муніципалітету. Цей представницький орган мав право давати директиви виконавчим органам ради та контролювати їхню діяльність. Строком на один рік обиралася президія ради, до якої входили обраний 3-поміж депутатів голова 
ради, секретар та їх заступники. Незважаючи на формальну демократичність Положення 1946 р., перші вибори до рад громад та представницьких органів округів (крайстагів) показали зростання впливу Соціалістичної єдиної партії Нiмеччини та швидку розбудову диктатури. Радянська окупаційна влада забезпечила перевагу партійної номенклатури в муніципальному управлінні, перетворивши громади на слухняних виконавців їхньої волі [15, с. 38]. 3 цього часу можна говорити про більш як сорокарічний «час без самоуправління» [14, с. 22].

У 1952 р. зазнав суттєвих змін адміністративно-територіальний устрій НДР. Були ліквідовані землі (L nder), замість них запроваджено систему округів (Bezirke), а також збільшено кількість районів (Kreise) [11]. Земля Бранденбург, приміром, була поділена на три округи: Котбус, Франкфурт-на-Одері та Потсдам. Громаду як самоврядне утворення було позбавлено статусу юридичної особи і перетворено на низову територіальну структуру держави. В цей час публічне управління будується згідно 3 радянським принципом «подвійного підпорядкування». Хоча рада громади залишалася вищим органом влади, її рішення могли бути скасовані радою вищого рівня.

Остаточно інститут місцевого самоврядування був ліквідований Законом про місцеві органи державної влади 1957 р., відповідно до якого на кожному рівні управління (громада, округ, район) функціонувала відповідна рада, яка обирала комітет та його голову як колегіальний виконавчий орган. Цей комітет був одночасно відповідальним як перед радою, яка його обирала, так і перед виконавчим комітетом вищого рівня [9]. Ліквідація незалежного місцевого самоврядування була підкріплена Конституцією НДР 1968 р. Відповідно до ст. 81 цього документа обов'язком громад було виконання місцевих державних завдань без можливості мати власну компетенцію. Місцеві депутати були практично позбавлені права самостійно приймати рішення, натомість зобов'язувалися «виховувати громадян у соціалістичному дусі та роз'яснювати їм політику державного керівництва» [5].

Падіння Берлінської стіни в листопаді 1989 р. стала початком процесу об'єднання Німеччини та побудови демократичних інституцій на території колишньої НДР. У травні 1990 р. перша демократично обрана Народна Палата НДР приймає Закон про самоврядування громад та районів в НДР, яким відновлено статус громади як самостійного від держави суб'єкта владних повноважень з власною компетенцією [10]. До системи органів місцевого самоврядування належали рада муніципалітету та бургомістр. Депутати ради обиралися жителями громади строком на чотири роки. Керівництво представницьким органом здійснював обраний з-поміж депутатів голова ради. Закон передбачав можливість створення у містах-районах президії, до якої входили голова ради, його заступники і бургомістр. Структурними частинами ради були депутатські комісії. Закон передбачав обов'язкове створення головного комітету, комісії 3 питань бюджету та ревізійну комісію. Рада могла вільно визначати подальшу модель її структурних частин у статуті громади.

Необхідно звернути увагу на те, що бургомістр обирався більшістю від складу ради на строк їі повноважень й очолював головний комітет та їі виконавчі органи. Він здійснював підготовку проектів і виконання прийнятих радою рішень, був наділений залишковою компетенцією в порівнянні 3 радою, яка могла вирішувати будь-яке питання місцевого значення. Закон про самоврядування громад та районів в НДР відновив інститут місцевого самоврядування та запропонував першу демократичну модель владних відносин між органами самоврядування в громадах нової федеральної землі Бранденбург, утвореної 3 жовтня 1990 р. на підставі Договору про об'єднання Німеччини [18].

Сучасний етап розвитку системи місцевого самоврядування характеризується тенденціями до уніфікації моделей організації самоврядної влади у громадах Німеччини. Результатом муніци- 
пальної реформи кін. XX ст. - поч. XXI ст. було приведення більшості земельних законів про муніципальний устрій у відповідність до основ південнонімецької моделі управління зі збереженням певних особливостей побудови i функціонування системи органів місцевого самоврядування у різних федеральних землях.

Визначальним для класифікації сучасних моделей муніципального управління $€$ критерій належності керівної компетенції одному з двох голов них органів влади громади (раді або бургомістру) чи її розподіл між обома суб'єктами владних повноважень. Таким чином, вирізняють дві дуалістичні моделі: «рада - бургомістр з одним управлінським центром» та "рада - бургомістр з подвійним управлінським центром». Відносини влади між ключовими органами в громаді, важелі взаємного впливу, система «стримувань і противаг» схематично зображені на рис. 1. i рис. 2.

Обраний жителями громади бургомістр (голова муніципалітету) очолюе представницький орган (раду) та здійснює одноосібне керівництво виконавчими органами ради (муніципальною адміністрацією). Незважаючи на те, що рада визнається першим головним органом муніципальної влади, яка володіє загальною універсальною компетенцією, бургомістр відіграє домінуючу роль у системі місцевої влади [13, с. 104]. Як голова представницького органу він наділений значними інструментами впливу всередині ради. Поряд з пов новаженнями підготовки та ведення пленарних засідань бургомістр формує порядок денний сесій та відповідає за виконання рішень ради. Більше того, цей владний суб'єкт є головою всіх депутатських комісій за посадою. Зважаючи на таке сильне позиціонування бургомістра, рада передає йому велику частину власної компетенції. Таким чином, бургомістр об'єднує дві частини ради в широкому розумінні, тобто орган волевиявлення (представництво громади) та управлінський апарат (виконавчі органи). Ця модель існує у землях БаденВюртемберг, Баварія, Північний РейнВестфалія, Райнланд-Пфальц, Саарланд, Саксонія та Тюрінгія.

Ця модель організації самоврядної влади (рис. 2) поєднує в собі елементи південнонімецького та традиційного для громад Бранденбурга «Штайнівського» або «несправжньо магістратного» типу управління. Місцеве самоврядування

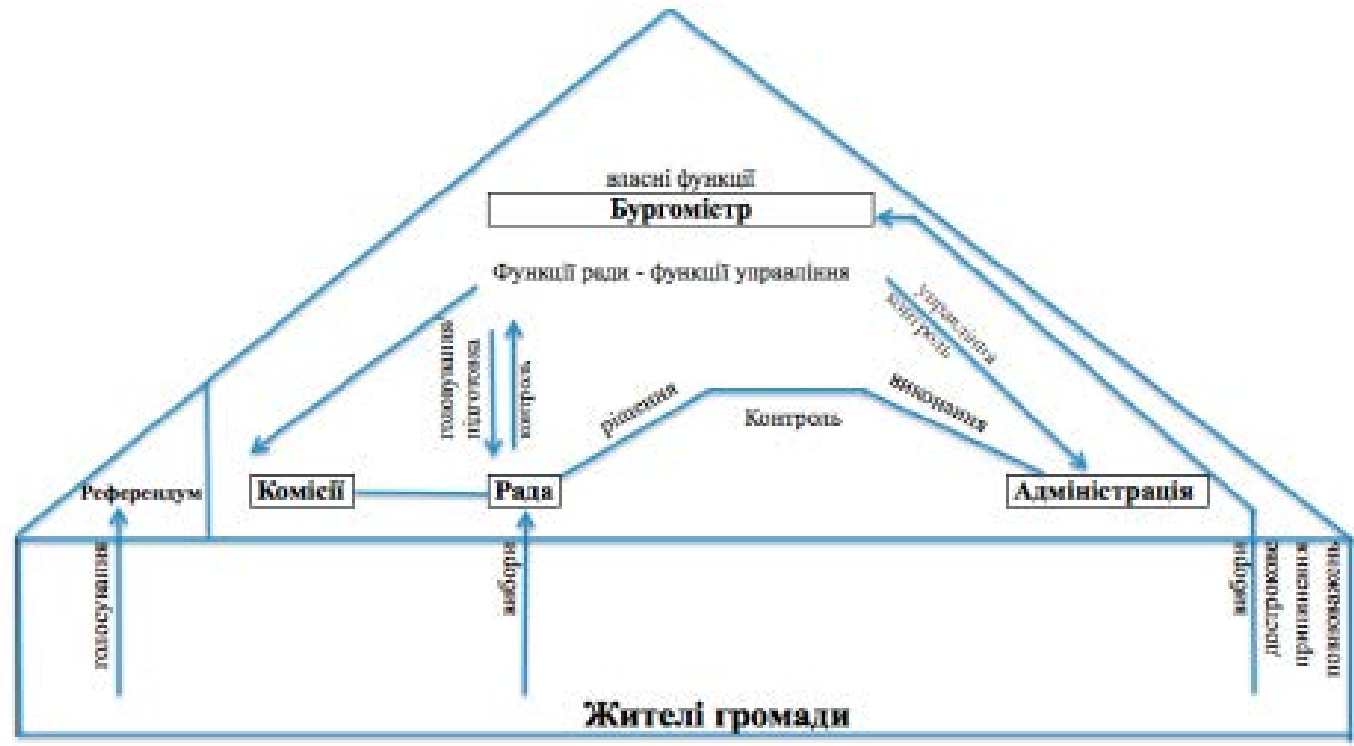

Рис. 1. Модель «рада - бургомістр з одним управлінським центром». 


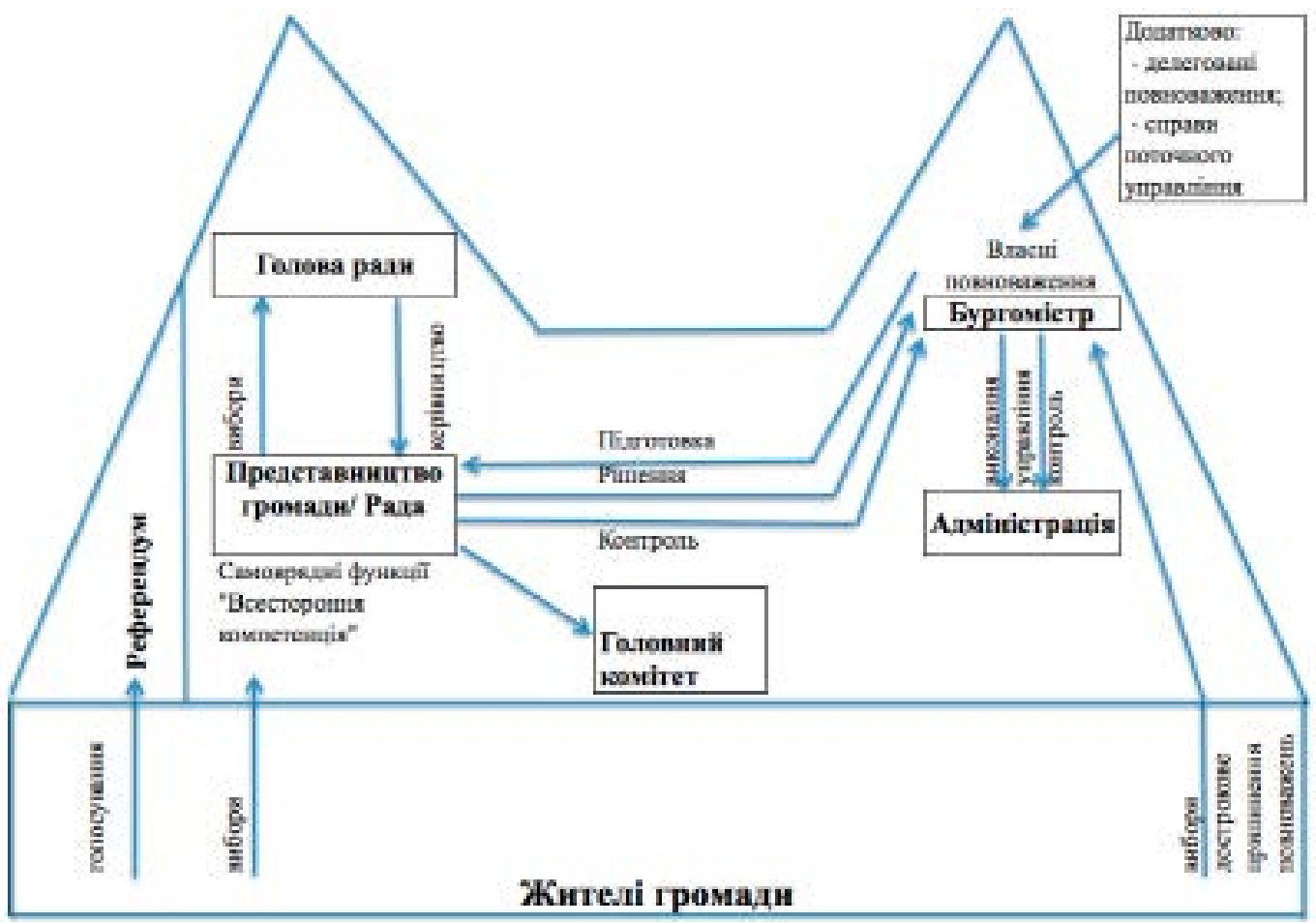

Рис. 2. Модель «рада - бургомістр з подвійним управлінським центром».

у федеральних землях Мекленбург-Передня Померанія, Саксонія-Ангальт і Шлезвіг-Гольштайн також функціонує згідно з цію моделлю. У Нижній Саксонії громади можуть обирати між першим і другим варіантами.

Обраний жителями громади бургомістр як керівник муніципальної адміністрації та голова ради, який обирається з числа її депутатів і очолює їі, формують подвійне політичне керівництво системою управління громадою. На перший погляд, видається, що обидва владні суб'єкти мають рівноцінне значення 3 точки зору обсягу компетенції, однак детальніший аналіз свідчить про необІрунтованість цього твердження. Голова ради не має важелів впливу на реалізацію бургомістром своєї компетенції. Натомість таким інструментом володіє голова муніципалітету. Хоча голова ради формує, наприклад, порядок денний, але його остаточний проект узгоджується 3 бургомістром. Та все-таки потрібно наголосити, що роль представництва громади у цій системі є значно вагомішою, ніж у моделі з одним управлінським центром. Той факт, що бургомістр позбавлений права головування в раді, істотно зменшує його політичний та особистісний вплив на рішення представницького органу. Окрім цього, рада громади формує головний комітет, до якого входять бургомістр та делеговані радою депутати. Головний комітет $\mathrm{\epsilon}$ «майданчиком» для взаємного врахування інтере сів представництва громади і виконавчих органів ради на чолі з бургомістром.

Висновки. Зважаючи на вищесказане, пропонуємо провести періодизацію еволюції системи місцевого самоврядування землі Бранденбург у 6 етапів: 1. Утвердження міст як автономних цент рів політичного, економічного та культурного життя (XII-XIII ст.); 2. Розвиток врядування в умовах магдебурзького права (XIII-XVII ст.); 3. Перетворення місцевого самоврядування у низову ланку суперцентралізованого державного управління Пруссії (друга пол. XVII - 
кін. XVIII ст.); 4. Розвиток магістратного типу управління та встановлення основ сучасної моделі місцевого самоврядування Бранденбурга (поч. XIX 20-i pp. XX ст.); 5. Муніципальний устрій в умовах тоталітаризму (19331990 рр.); 6. Проведення муніципальної реформи й повернення до демократичного місцевого самоврядування (з 1990 р.).

В процесі історичного розвитку та як результат реалізації законодавчої компетенції німецькими землями сформувалися чотири типи організації влади у громаді: північнонімецький, півден- нонімецький, рейнський бургомістерський та магістратний. Сучасний муніципальний устрій абсолютної більшості суб'єктів федерації грунтується на південнонімецькій моделі, яка виражається у двох варіантах: «рада - бургомістр з одним управлінським центром» та «рада - бургомістр з подвійним управлінським центром». Ці моделі організації взаємовідносин між органами місцевого самоврядування повинні стати об'єктом грунтовних досліджень на предмет ефективності та доцільності їх запровадження в Україні.

БІБАІОГРАФІЧНІ ПОСИААННЯ:

1. Кохалик Х. М. Досвід становлення і розвитку комунального самоврядування в Німеччині та можливість його адаптації в містах України [Текст] : автореф. дис. ... канд. наук з держ. упр. : 25.00.04 / X. M. Кохалик; Львів. регіон. ін-т держ. упр. Нац. акад. держ. упр. при Президентові України. - Львів: [б. в.], $2011 .-20$ с.

2. Організація та функціонування представницьких органів місцевого самоврядування в зарубіжних країнах [Текст] : наук. розроб. / авт. кол. : О.Д. Лазор, Х.М. Кохалик, І.П. Шелепницька [та ін.] ; за наук. ред. О. Д. Лазор. - К. : НАДУ, 2009. - 44 c.

3. Demokratische Gemeindeverfassung für die sowjetische Besatzungszone Deutschlands vom September/Oktober 1946 [Електронний ресурс] // Amtsblatt der Landesverwaltung Mecklenburg-Vorpommern 1946 S. 113. - Режим доступу: http://www.verfassungen.de/de/mv/gemeindeverfassung $46 . \mathrm{htm}$.

4. Deutsche Gemeindeordnung vom 30. Januar 1935 [Електронний pecypc] // Reichsgesetzblatt 1935 I S. 49. Режим доступу: http://www.verfassungen.de/de/de33-45/gemeindeordnung35.htm.

5. Die Verfassung der Deutschen Demokratischen Republik vom 6. April 1968 in der Fassung vom 7 . Oktober 1974 [Електронний ресурс] // Gesetzblatt der DDR 1974 I S. 432. - Режим доступу: http://www.documentarchiv.de/ ddr.html.

6. Die Verfassung des Deutschen Reichs «Weimarer Reichsverfassung» vom 11. August 1919 [Електронний ресурс] // Режим доступу: http://www.documentarchiv.de/wr/wrv.html

7. Engeli C. Quellen zum modernen Gemeindeverfassung in Deutschland / C. Engeli, W. Haus (Hrsg.). - Stuttgart: Kohlhammer, 1975. - 811 S.

8. Gern A. Deutsches Kommunalrecht / A. Gern [Текст]. - 3. Aufl. - Baden-Baden: Nomos, 2003. - 766 S.

9. Gesetz über die örtlichen Organe der Staatsmacht vom 18. Januar 1957 [Електронний pecypc] // Gesetzblatt der DDR 1957 Teil I S. 65. - Режим доступу: http://www.verfassungen.de/de/ddr/kommunalverfassung57.htm. 10. Gesetz über die Selbstverwaltung der Gemeinden und Landkreise in der DDR (Kommunalverfassung) vom 17. Маi 1990 [Електронний ресурс] // Gesetzblatt der DDR 1990 I S. 255. - Режим доступу: http://www. verfassungen.de/de/ddr/ddr90-kommunalverfassung.htm.

11. Gesetz über die weitere Demokratisierung des Aufbaus und der Arbeitsweise der staatlichen Organe in den Ländern der DDR vom 23. Juli 1952 [Електронний ресурc] // Gesetzblatt der DDR 1952 S. 613. - Режим доступу: http://www.verfassungen.de/de/ddr/ddr52.htm.

12. Grundgesetz für die Bundesrepublik Deutschland vom 23. Mai 1949 (BGBl. S.1), zuletzt geändert durch das Gesetz vom 21.Juli 2010 (BGBl. S. 944) [Електронний ресурс] // Режим доступу : https://dejure.org/gesetze/ $\mathrm{GG} / 28 . \mathrm{html}$

13. Knemeyer F.-L. Gemeindeverfassungen / F.-L. Knemeyer // Kommunalpolitik: politisches Handeln in den Gemeinden / H. Wollmann / R. Roth (Hrsg.). - 2 Aufl. - Opladen: Leske und Budrich, 1999. - 104-122

14. Nierhaus M. Kommunalrecht für Brandenburg [Текст]. - Baden-Baden: Nomos, 2003. - $202 \mathrm{~S}$.

15. Schrameyer M. Das Verhältnis von Bürgermeister und Gemeindevertretung / M. Schrameyer. - Berlin: Erich Schmidt Verlag, 2006. - $230 \mathrm{~S}$.

16. Stier-Somlo F. Das Grundrecht der kommunalen Selbstverwaltung unter besonderer Berücksichtigung des Eingemeindungsrechtes / F. Stier-Somlo // Archiv des öffentlichen Rechtes [Tекст]. - 1929. - Bd. 17. - 1-12 S.

17. Verfassung des Deutschen Reiches vom 28. März 1849 [Електронний ресурс] // Режим доступу: http:// verfassungen.de/de/de06-66/verfassung48-i.htm.

18. Vertrag zwischen der Bundesrepublik Deutschland und der Deutschen Demokratischen Republik über die Herstellung der Einheit Deutschlands (Einigungsvertrag) vom 31.08.1990 [Електронний ресурс] Bundesgesetzblatt 1990 Teil II S. 889. - Режим доступу: http://www.gesetze-im-internet.de/bundesrecht/ einigvtr/gesamt.pdf.

\section{REFERENCES:}

1. Kokhalyk, Kh. M., 2011. Dosvid stanovlennya i rozvytku komunal'noho samovryaduvannya v Nimechchyni ta mozhlyvist' yoho adaptatsiyi v mistakh Ukrayiny [Experience the formation and development of municipal govern- 
ments in Germany and the possibility of adaptation in cities of Ukraine]. L'viv (in Ukrainian).

2. Orhanizatsiya ta funktsionuvannya predstavnyts'kykh orhaniv mistsevoho samovryaduvannya v zarubizhnykh

krayinakh [The organization and functioning of local governments in foreign countries]. 2009. NADU, Kyiv (in

Ukrainian).

3. Demokratische Gemeindeverfassung für die sowjetische Besatzungszone Deutschlands vom September/Oktober

1946. Amtsblatt der Landesverwaltung Mecklenburg-Vorpommern 1946. Access: http://www.verfassungen.de/

$\mathrm{de} / \mathrm{mv} /$ gemeindeverfassung46.htm.

4. Deutsche Gemeindeordnung vom 30. Januar 1935 . Reichsgesetzblatt 1935 I S. 49. Access: http://www. verfassungen.de/de/de33-45/gemeindeordnung35.htm.

5. Die Verfassung der Deutschen Demokratischen Republik vom 6. April 1968 in der Fassung vom 7 . Oktober 1974 . Gesetzblatt der DDR 1974 I S. 432. Access: http://www.documentarchiv.de/ddr.html.

6. Die Verfassung des Deutschen Reichs «Weimarer Reichsverfassung» vom 11. August 1919. Access: http:// www.documentarchiv.de/wr/wrv.html.

7. Engeli, C., 1975. Quellen zum modernen Gemeindeverfassung in Deutschland. - uttgart: Kohlhammer

8. Gern, A., 2003. Deutsches Kommunalrecht. Baden-Baden: Nomos

9. Gesetz über die örtlichen Organe der Staatsmacht vom 18. Januar 1957 . Gesetzblatt der DDR 1957 Teil. Access:

http://www.verfassungen.de/de/ddr/kommunalverfassung57.htm.

10. Gesetz über die Selbstverwaltung der Gemeinden und Landkreise in der DDR (Kommunalverfassung) vom 17. Mai 1990 . Gesetzblatt der DDR 1990. Access: http://www.verfassungen.de/de/ddr/ddr90-kommunalverfassung. htm.

11. Gesetz über die weitere Demokratisierung des Aufbaus und der Arbeitsweise der staatlichen Organe in den Ländern der DDR vom 23. Juli 1952 . Gesetzblatt der DDR 1952. Access: http://www.verfassungen.de/de/ddr/ ddr52.htm.

12. Grundgesetz für die Bundesrepublik Deutschland vom 23. Mai 1949 (BGBl. S.1), zuletzt geändert durch das Gesetz vom 21.Juli 2010 (BGBl. S. 944). Access: https://dejure.org/gesetze/GG/28.html.

13. Knemeyer, F.-L., 1999. Gemeindeverfassungen. Kommunalpolitik: politisches Handeln in den Gemeinden. Opladen: Leske und Budrich

14. Nierhaus, M., 2003. Kommunalrecht für Brandenburg. Baden-Baden: Nomos

15. Schrameyer, M., 2006. Das Verhältnis von Bürgermeister und Gemeindevertretung. Berlin: Erich Schmidt Verlag

16. Stier-Somlo, F., 1929. Das Grundrecht der kommunalen Selbstverwaltung unter besonderer Berücksichtigung des Eingemeindungsrechtes. Archiv des öffentlichen Rechtes 17, 1-12

17. Verfassung des Deutschen Reiches vom 28. März 1849. Access: http://verfassungen.de/de/de06-66/ verfassung 48-i.htm.

18. Vertrag zwischen der Bundesrepublik Deutschland und der Deutschen Demokratischen Republik über die Herstellung der Einheit Deutschlands (Einigungsvertrag) vom 31.08.1990. Bundesgesetzblatt 1990 Teil II S. 889. Access: http://www.gesetze-im-internet.de/bundesrecht/einigvtr/gesamt.pdf

Красівський Орест Якубович - доктор історичних наук, професор

Львівський регіональний інститут державного управління Національної акаделї̈ державного управління при Президентові Украӥни

Адреса: 79491, Львів-Брюховичі, вул. Сухоллинського, 16

E-mail:krasivski@ukr.net

Янишевський Маркіян Мар'янович - здобувач

Львівський регіональний інститут державного управління Національної акаделї̈ державного управління при Президентові України

Адреса: 79491, Львів-Брюховичі, вул. Сухоллинського, 16

E-mail: markiyan.yanyshevskyy@gmail.com

Krasivskyy Orest $\mathbf{Y}$. - doctor of historical sciences, Full Prof.

Lviv regional institute of public administration National academy of public administration, the Office of the President of Ukraine

Address: 16, Suhomlynskyy Str., Lviv-Briukhovychi, 79491

Yanyshevskyy Markiyan M. - applicant

Lviv regional institute of public administration National academy of public administration, the Office of the President of Ukraine

Address: 16, Suhomlynskyy Str., Lviv-Briukhovychi, 79491

Красивский Орест Якубович - доктор исторических наук, профессор

Львовский региональный институт государственного управления Национальной академии государственного управления при Президенте Украины Адрес: 79491, Львов-Брюховичи, ул. Сухоллинского, 16

Янышевский Маркиян Марьянович-соискатель

Львовский региональный институт государственного управления Национальной академии государственного управления при Президенте Украины

Адрес: 79491, Львов-Брюховичи, ул. Сухоллинского, 16 